\title{
Francisco, a la vuelta de la esquina
}

José Emilio Ortega ${ }^{1}$

No compartimos espacio ni proyectos, en aquellos buenos tiempos de política universitaria. Y en rigor de verdad, siempre voté a otra boleta, en elecciones que lo tuvieron como candidato. No me concierne evocar su historial académico y mucho menos su extensa labor política. Tampoco, a ciencia cierta, me cabe despedir al amigo. Pero una extraña sensación, me compele a recordarlo y compartir ese recuerdo, a horas de su desaparición física.

Encuentro en la memoria, con claridad, la primera vez que conversamos, arrancaba la década del noventa. El era, ni más ni menos, que el Rector de la Universidad Nacional de Córdoba, antes exitoso normalizadorde la Universidad de Buenos Aires -entre 1984 y 1985-. Un hombre enérgico, pensante, con cara de pocos amigos, mirada intensa y trato amable -aunque nos habían advertido que no lo hiciéramos enojar-. Contundente a la hora de decidir. De aquel encuentro guardo algunas lecciones simples e inolvidables por lo elementales y valiosas. Ya no volví a cruzarlo personalmente hasta amanecido el siglo XXI, cuando coincidimos, empujando diversos proyectos, en el Centro de Estudios Avanzados que él había fundado. A partir de allí el trato fue más frecuente, y con los años, cada vez más afectuoso.

Y por fin pude conocer a Francisco José en profundidad, descubrir sus múltiples facetas, abrevar de su energía constante. Caminaba como un político, respiraba como un sociólogo, razonaba como un abogado, se expresaba fluyendo entre la precisión del periodista, la erudición del ensayista y la imaginación del narrador más creativo. Sentía como un argentino enamorado de su país, de sus problemas y desafíos, de su inserción en Latinoamérica. Del acople de ésta con el resto del mundo.

Francisco, «el polaco», Pancho o simplemente «Delich». El era todos ellos y todos ellos eran él. Incansable e inquieto, recorrió largos y

\footnotetext{
${ }^{1}$ Director de la Editorial de la Universidad Nacional de Córdoba. Elaboró su tesis de Maestría bajo la dirección de Francisco Delich.
} 
diversos caminos. Sus experiencias de vida, vastísimas, generaban a cada paso una nueva reflexión. Pocas personas en Córdoba, como él, poseyeron esa extraordinaria capacidad de pensar a cada momento, y escribirlo. Lo acredita su enorme testimonio bibliográfico, valorado en el mundo entero, que ojalá nuestra Universidad edite como las Obras Completas de quien fue sin duda uno de sus intelectuales más sobresalientes. Lo testimonian sus permanentes indagaciones, preocupaciones, que compartía con sus colegas o amistades, en el modesto cubículo que ocupó hasta estos días en el CEA, o en ronda de café, o en una visita a su despojado departamento de Nueva Córdoba entre conversaciones que podían tomar el rumbo más variado. $\mathrm{O}$ en sus siempre esperadas apostillas que puntualmente llegaron hasta hace pocos días a las casillas de correo de algunos de sus contactos.

Pero no debemos olvidarnos del Delich gestor. Las Universidades que dirigió, mantienen hasta la actualidad programas, áreas o estructuras que él definió y cuentan en lugares clave con el aporte de personas que él supo elegir y promover hace más de dos décadas. En su último libro, «808 días» (Eudeba, 2015), realizó una magistral pintura del regreso de la Argentina a la democracia y del rol de la Universidad Pública maniobrando en difícil terreno, apuntalando esa difícil transición. No obstante el texto, sus recuerdos personales, y sus lecciones en clave de presente a partir de la ruta recorrida, completarán esa mirada y serán parte de un tesoro que legó a quienes lo frecuentaron.

Sin pretender una posición que -insisto- no me corresponde, intento concretar esta irrefrenable necesidad de memorar a Delich. Como uno más de los tantos que, de un modo u otro, y en ambientes, escenarios o instituciones diversas, sentían y sabían que Francisco, a pesar de la celebridad del personaje, estaba a la vuelta de la esquina. En lo personal, me quedan sus consejos -académicos y de vida- su calidez y humildad. A todos, les aprovechará su reconocida obra, sus concretas realizaciones. Y también, su ejemplo. 